\title{
AVALIAÇÃO DE UM CURSO DE FORMAÇÃO CONTINUADA COMO MÉTODO DE CAPACITAÇÃO DE PROFESSORES DO ENSINO MÉDIO EM GENÉTICA
}

\section{Evaluation of a Continuing Education Course as Method of Capacitation of High School Teachers in Genetics}

\author{
Ronaldo dos Santos Filho ${ }^{1}$ \\ Lupe Furtado Alle ${ }^{2}$ \\ Marta Margarete Cestari ${ }^{3}$ \\ Daniela Morais Leme ${ }^{4}$
}

\begin{abstract}
Resumo: Os conteúdos de Genética são apontados por alunos e professores de Biologia entre os mais complexos do Ensino Médio. Este artigo tem como proposta descrever a elaboração e avaliar o potencial e as eventuais limitações de um curso de formação continuada em Genética para professores de Biologia, visando minimizar as dificuldades de ensino-aprendizagem nesta temática. Inicialmente, para a estruturação do curso, os autores aplicaram questionários de diagnóstico relacionados ao processo de ensino-aprendizagem de Genética com alunos $(n=1140)$ e professores de Biologia $(n=52)$ de 40 escolas estaduais de Curitiba/PR. A partir dos dados coletados verificamos que a não utilização de metodologias alternativas no ensino de Genética era um dos principais fatores associados às dificuldades de aprendizado dos estudantes. Adicionalmente, observamos que a baixa utilização dessas metodologias estava relacionada com as defasagens teórica e prática dos professores em Genética. Objetivando minimizar as defasagens teórico-práticas dos docentes, estruturamos e realizamos o curso "Desenrolando a Genética", com 33 professores e em dez módulos. O potencial e as eventuais limitações do curso foram mensurados a partir de respostas dadas aos questionários comparativos aplicados no início e no final do curso e de formulários que registraram a visão dos professores participantes em relação às atividades realizadas e ao curso. Estes dados indicaram que, apesar de conter pequenas limitações, o curso contribuiu para minimizar as defasagens teórica e prática dos docentes, possibilitando um melhor ensino de Genética nas escolas. Estudos futuros são necessários para verificar se os estudantes estão reduzindo suas dificuldades de aprendizado em Genética.
\end{abstract}

Palavras-chave: Metodologias Alternativas. Formação Continuada. Ensino de Genética.

\footnotetext{
${ }^{1}$ Doutor em Genética pelo Programa de pós-graduação em Genética da Universidade Federal do Paraná (UFPR). E-mail: ronaldosantosf90@gmail.com ORCID: 0000-0003-4668-2361

${ }^{2}$ Doutora em Genética. Professora do Programa de pós-graduação em Genética da Universidade Federal do Paraná (UFPR). E-mail: lupealle@gmail.com ORCID: 0000-0002-1616-8225

3 Doutora em Ecologia e Recursos Naturais. Professora do Programa de pós-graduação em Genética da Universidade Federal do Paraná (UFPR). E-mail: margaces@gmail.com ORCID: 0000-0001-6064-966X

4 Doutora em Biologia Celular e Molecular. Professora do Programa de pós-graduação em Genética da Universidade Federal do Paraná. E-mail: daniela.leme@ufpr.br ORCID: 0000-0001-7164-1276
} 

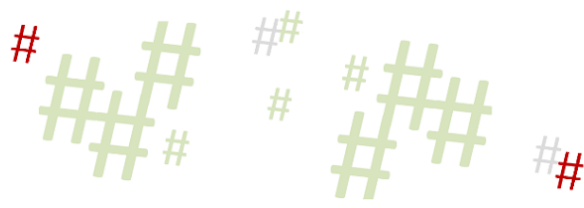

Abstract: Genetics' contents are pointed out by Biology students and teachers among the most complex in high school. This article aims to describe the elaboration and to evaluate the potential and possible limitations of a continuing education course in Genetics for Biology teachers, as a method to minimize teaching-learning difficulties in this subject. Initially, in order to structure the course, the authors applied diagnostic questionnaires related to the teachinglearning process of Genetics with students $(n=1140)$ and Biology teachers $(n=52)$ from 40 public schools in Curitiba/PR. From the data collected, we verified that the non-use of alternative teaching methodologies in Genetics was one of the main factors associated with students' learning difficulties. Additionally, we observed that the low use of these methodologies was related to the theoretical and practical gaps of Biology's teachers about Genetics. Aiming to minimize the theoretical-practical lags of teachers, we structured and carried out the course "Desenrolando a Genética" with 33 teachers in ten modules. The potential and limitations of the course were measured from responses given to comparative questionnaires at the beginning and the end of the course and from forms that reported the participating teachers' viewpoints in relation to the activities carried out and the course. These data indicated that despite small limitations, the course contributed to minimizing the theoretical and practical gaps of the teachers, enabling better teaching of genetics at schools. Future studies are needed to verify whether students are reducing their learning difficulties in Genetics.

Keywords: Alternative methodologies. Continuing Education. Genetics teaching.

\section{Introdução}

A Educação Básica Brasileira tem apresentado resultados insatisfatórios nos últimos anos, apontados pela baixa pontuação do Brasil no Programa Internacional de Avaliação de Estudantes (PISA) (OECD, 2018). Três fatores parecem contribuir com esta problemática. O primeiro é que muitos conteúdos são ministrados em pouco tempo visando atender a estrutura curricular do Ensino Médio e preparar os alunos para o vestibular (MOSÉ, 2013). O segundo fator é a metodologia de ensino predominantemente teórica, com aulas expositivas, nas quais o aluno é coadjuvante do processo de ensino-aprendizagem (BISSOLI; SANTOS; CONDE, 2018). O terceiro fator está relacionado com a alta carga horária dos professores em sala de aula, o que dificulta o preparo de aulas e atividades mais dinâmicas (SOUZA, 2014).

As diretrizes da nova Base Nacional Comum Curricular (BNCC) estabelecem que o ensino de Ciências deve capacitar os estudantes para associar o conhecimento científico adquirido na escola com a solução de problemas cotidianos (MEC, 2018). No entanto, em muitas escolas o ensino de ciências ainda possui uma abordagem extremamente teórica e conceitual (OLIVEIRA, 2013). Em especial, os conteúdos de Genética são considerados como de difícil compreensão, uma vez que possuem uma terminologia ampla e complexa, envolvem operações matemáticas e conteúdos abstratos. É importante contextualizar que o uso do termo "conteúdo abstrato" nesse artigo refere-se aos conteúdos que acontecem em nível microscópico e que não são facilmente associados com imagens ou objetos do cotidiano dos estudantes (KNIPPELS; WAARLO; BOERSMA, 2005; BELMIRO; BARROS, 2017).

O cenário supracitado indica a importância de adequações na forma de ensino da Educação Básica Brasileira. No entanto, isso só será possível com a participação de todos os envolvidos no processo educacional. Diante disso, de modo a fornecer a nossa contribuição como pesquisadores, estabelecemos como questão norteadora deste estudo a busca por uma 
maneira de auxiliar os professores a enfrentarem as suas dificuldades e a prepararem aulas de Genética mais dinâmicas, contribuindo com o processo de ensino-aprendizagem desta temática.

Nesse estudo, hipotetizamos que as dificuldades dos alunos em Genética estão relacionadas com as dificuldades de seus professores nesta área, e que a realização de um curso de formação com este tema ajudaria a minimizar essa problemática. Dessa forma, este estudo objetivou descrever a elaboração e avaliar o potencial e as eventuais limitações de um curso de formação continuada em Genética como proposta para minimizar as dificuldades dos professores nesta área, contribuindo com o processo de ensino-aprendizagem de Genética.

\section{Referencial Teórico}

Os conteúdos de Genética são citados entre os mais difíceis de ensinar e aprender em Biologia por alunos e professores do Ensino Médio (HAAMBOKOMA, 2007; BELMIRO; BARROS, 2017). Os principais fatores responsáveis por essas dificuldades são: a terminologia complexa; as concepções prévias e equivocadas dos alunos sobre alguns conceitos; o envolvimento da matemática; o predomínio de aulas expositivas; e o fato de os conteúdos de Genética serem considerados abstratos (KNIPPELS, WAARLO; BOESRMA, 2005; HAAMBOKOMA, 2007; BELMIRO; BARROS, 2017).

Em relação à problemática associada à terminologia, é preciso considerar dois aspectos. O primeiro deles é a grande quantidade de conceitos apresentados aos alunos (HAAMBOKOMA, 2007). Em geral os termos são complexos (ex. epistasia, genótipo) e em alguns casos são escritos e pronunciados de forma semelhante, embora possuam definições diferentes (ex. heterozigoto, heterose). O segundo aspecto considera as concepções equivocadas que os alunos possuem sobre alguns termos e que são oriundas da reprodução incorreta de conceitos de genética nos meios de comunicação (SHAW et al., 2008).

O uso da matemática na solução de problemas e cruzamentos genéticos é outro obstáculo para o processo de ensino-aprendizagem dessa área. De acordo com Bahar, Johnstone e Hansell (2000), a utilização da probabilidade nos cruzamentos genéticos requer habilidades lógicas e numéricas presentes em poucos conteúdos de Biologia. Além disso, a relação entre matemática e genética não é ensinada de forma adequada, pois os alunos memorizam as proporções de um cruzamento utilizando o quadrado de Punnett, mas sem compreender os conceitos e processos genéticos que explicam tais probabilidades. A possível explicação para a carência de uma melhor conexão entre estas duas vertentes, está em falhas na abordagem matemática dos cursos superiores de Ciências Biológicas (SATTERHWAIT, 2019).

Por fim, a metodologia tradicional de ensino, através de aulas expositivas, não costuma favorecer o aprendizado de Genética (BELMIRO; BARROS, 2017). Isso acontece porque o ensino de Genética envolve processos que acontecem em nível celular sendo, portanto, um conteúdo abstrato para os alunos, o que dificulta a visualização e a compreensão de processos celulares que acontecem a nível microscópico (ex. transcrição, divisão celular, segregação cromossômica) (KNIPPELS; WAARLO; BOERSMA, 2005).

Nesse sentido, é importante destacar que a metodologia tradicional de ensino (aulas expositivas) tem sido criticada nos últimos anos por dois fatores. O primeiro é por não contemplar os diferentes tipos de inteligência e aprendizado dos estudantes, favorecendo somente o aprendizado dos alunos que possuam inteligências do tipo linguística ou lógicomatemática (CHEN; MORAN; GARDNER, 2009). O segundo é por não dar protagonismo aos estudantes, que costumam ser meros coadjuvantes do processo de ensino-aprendizado, que é focado no professor, no quadro e no livro didático (BISSOLI; SANTOS; CONDE, 2018). 
Diante disso, metodologias alternativas e ativas de aprendizagem têm sido cada vez mais utilizadas nas diversas áreas do saber para minimizar as dificuldades de aprendizagem em ciências (YAMAZAKI, S; YAMAZAKI, R, 2006)

É possível definir as metodologias alternativas de ensino como quaisquer recursos didáticos utilizados pelo professor que vão além da aula expositiva, do quadro e do livro didático. A utilização desses recursos contribui com o aprendizado dos estudantes, mas não assegura o seu protagonismo em sala de aula. Esse protagonismo é assegurado a partir das metodologias ativas de ensino, nas quais o aluno tem contato direto com a produção do conhecimento (BISSOLI; SANTOS; CONDE, 2018).

É importante ponderar que as metodologias alternativas de ensino e a metodologia ativa de aprendizagem têm sido utilizadas em diversos países no ensino de Genética (BREAKLEY et al., 2008; FONTENELE; CAMPOS, 2017). No entanto, ainda se percebe uma limitação do uso destas propostas no ensino de Genética no Brasil, o que pode estar associado ao pouco tempo que os professores têm para prepararem aulas mais dinâmicas (SOUZA, 2014) e às dificuldades dos docentes em Genética, oriundas de uma formação universitária pouco eficaz (SATTERHWAIT, 2019). Diante disso, cursos de formação continuada podem ser utilizados e contribuir com a formação docente (SILVA; SANTOS, 2020). Embora cursos de formação continuada de Genética não sejam reportados com frequência na literatura, o estudo de Marques, Persich e Neto (2017) identificou que os professores de biologia gostariam de cursar uma formação continuada na área. Essa informação reforça a importância das formações continuadas e da inclusão desses cursos na área de Genética para a comunidade docente.

\section{Metodologia}

Esta pesquisa apresenta natureza aplicada e é do tipo quanti-qualitativa. O Comitê de Ética em Pesquisa com Seres Humanos (CEP) da Universidade Federal do Paraná aprovou a realização dessa pesquisa sob o parecer $\mathrm{n}^{\circ}$ 2.224.172. O presente estudo aconteceu em duas etapas, cujos detalhes metodológicos estão descritos nos subitens 3.1 e 3.2 desta seção.

\subsection{Etapa 1 - Questionários de diagnóstico}

Inicialmente os pesquisadores elaboraram dois tipos de questionários de diagnóstico, um destinado para alunos (Apêndice A) e outro para professores (Apêndice B). Os questionários eram relacionados ao processo de ensino-aprendizagem de Genética no Ensino Médio e buscavam: (1) Identificar e quantificar fatores relacionados às dificuldades de aprendizagem de Genética dos alunos; (2) Quantificar a utilização de alternativas metodológicas no processo de ensino-aprendizagem de Genética e (3) Elencar informações relacionadas às dificuldades existentes no processo de ensino-aprendizagem de Genética para direcionar a elaboração de um curso de formação continuada em Genética para professores de Biologia.

Os pesquisadores aplicaram os questionários em 40 escolas estaduais de Curitiba/PR, a partir de uma parceria com a Secretária Estadual de Educação do Paraná. No total 1140 alunos do terceiro ano do Ensino Médio, sendo 51\% (n=582) do sexo feminino e 49\% (n=558) do sexo masculino e 52 docentes de Biologia, sendo $67 \%(n=35)$ do sexo feminino e $33 \%(n=17)$ do sexo masculino responderam aos questionários aplicados em sala de aula.

O questionário aplicado aos estudantes era composto de cinco questões que mensuravam a percepção do aluno acerca do seu grau de interesse e de dificuldade em Genética, dos fatores 
dificultadores para a sua aprendizagem de Genética, além de informações sobre o seu acesso e interesse pela utilização de metodologias alternativas de ensino nessa temática. O questionário diagnóstico aplicado aos professores também apresentava cinco questões. A primeira era uma questão relacionada ao interesse do professor por Genética. A segunda questão identificava a percepção do professor sobre sua formação - acerca da existência de defasagem teórica (falta de domínio do conhecimento teórico) ou prática (falta de habilidade e/ou conhecimento para realizar atividades práticas) em Genética. As demais questões foram elaboradas para identificar o ponto de vista dos docentes em relação aos fatores que dificultam o ensino de Genética, aos fatores que limitam a utilização das metodologias alternativas de ensino em Genética e sobre o interesse em participar de um curso de formação continuada nesta temática.

Os dados obtidos dos questionários foram tabulados e apresentados em frequência percentual das respostas obtidas para cada questão. Em algumas questões era possível assinalar mais de uma alternativa como resposta (caso mais de um fator fosse considerado relevante). Nesses casos, a soma da frequência percentual das respostas ultrapassou $100 \%$ e as análises percentuais foram realizadas considerando o percentual de participantes que assinalaram ou não determinada alternativa. A verificação dos dados na forma de frequência percentual permitiu sintetizar as principais informações relacionadas ao processo de ensino-aprendizagem de Genética nos dois grupos avaliados (alunos e professores). A partir da identificação dos principais resultados, foram realizadas análises de regressão múltipla ( $p<0,05$; Software $R$ ) em duas questões do questionário dos alunos para uma melhor interpretação dos dados. Esta análise permite observar a influência de diferentes fatores (variáveis independentes) sob um aspecto em particular (variável dependente). Dentre as variáveis independentes observadas, incluímos o sexo dos alunos e professores, uma vez que a Genética requer conhecimentos matemáticos e existem estudos que apontam maiores dificuldades das mulheres em compreender matemática.

A primeira questão escolhida e testada como variável dependente foi a questão relacionada ao grau de dificuldade atribuído pelo aluno para os conteúdos de Genética (muito difícil, difícil, regular ou fácil). As variáveis independentes utilizadas poderiam estar relacionadas ao aluno (escola, sexo, nota de interesse por Genética, fatores que dificultam o aprendizado de Genética) ou ao professor (sexo do professor, interesse por genética, defasagem teórica e defasagem prática). A justificativa para realização da análise de regressão múltipla nesta questão é a importância de uma melhor interpretação dos fatores que estão relacionados com os diferentes graus de dificuldades dos estudantes em Genética.

A segunda questão escolhida e testada como variável dependente foi a questão em que os alunos indicavam se já haviam tido acesso a metodologias alternativas de ensino de Genética ( sim ou não). As variáveis independentes utilizadas estavam relacionadas somente ao professor - responsável por escolher a metodologia (nota de interesse em Genética, defasagem teóricoprática em Genética, envolvimento da matemática, complexidade dos termos e processos, dificuldade em utilizar metodologias alternativas de ensino e formação universitária insuficiente). A justificativa para realização da análise de regressão múltipla nesta questão é para buscar uma melhor compreensão do alto percentual de alunos que nunca teve acesso a aulas de Genética com metodologias alternativas de ensino.

\subsection{Etapa 2 - Curso de formação continuada "Desenrolando a Genética"}

Os pesquisadores desenvolveram e realizaram o curso "Desenrolando a Genética" em 2018 com professores de Biologia visando minimizar as dificuldades no processo de ensinoaprendizagem de Genética. O curso foi estruturado a partir das informações coletadas nos questionários aplicados com alunos e professores na primeira etapa desta pesquisa. 
O curso "Desenrolando a Genética" foi realizado em dez módulos. Em cada módulo houve um encontro presencial de quatro horas, dividido em dois momentos. No primeiro momento era realizada uma revisão teórica de um conteúdo de Genética do Ensino Médio, visando minimizar a defasagem teórica dos docentes. No segundo momento, uma proposta de metodologia alternativa de ensino de Genética relacionada ao conteúdo recém-ministrado era apresentada aos professores, visando minimizar a defasagem prática dos participantes. A inclusão dessas metodologias aconteceu devido à sua baixa utilização no ensino de Genética no Brasil e devido aos dados coletados nos questionários, que indicavam o interesse dos alunos por sua utilização. Apesar da preferência dos alunos por visitas às universidades, aulas práticas e aulas de campo, nós optamos por apresentar no curso metodologias alternativas que pudessem ser desenvolvidas pelos professores independentemente da infraestrutura da escola. Assim, as atividades propostas foram predominantemente caracterizadas por jogos, modelos didáticos e pelo uso da metodologia ativa. O conteúdo programático do curso e as dez propostas de metodologias alternativas de ensino de Genética podem ser observadas no Quadro 1.

Quadro 1 - Conteúdo programático e metodologias alternativas do Curso "Desenrolando a Genética. Curso "Desenrolando a Genética" - Conteúdo Programático e Metodologias Alternativas

Módulo 01: Teoria - Genética e organismo (Conceitos básicos de Genética, Estrutura do DNA)

- Metodologia alternativa 1 - Elaboração de dicionário de Genética: registrar os principais conceitos de Genética em um caderno. Conceitos são acrescentados ao longo das aulas. Adaptada de: https://educador.brasilescola.uol.com.br/estrategias-ensino/dicionario-biologia.htm;

- Metodologia alternativa 2 - Confecção de modelo didático do DNA: montar a estrutura do DNA com haste flexível e miçangas coloridas. Replicada de: https://pt.wikihow.com/Fazer-um-Modelo-deDNA-Usando-Materiais-Comuns;

- Questionário Inicial - Professores respondem à um questionário sobre Genética Básica.

Módulo 02: Teoria - Síntese Proteica e Mutações Gênicas.

- Metodologia alternativa 3 - Realização de jogo sobre síntese proteica: participantes devem recortar e colar o pareamento adequado das bases nitrogenadas nos processos de replicação e transcrição. $\mathrm{Na}$ sequência colar o aminoácido corresponde na etapa de tradução. Elaborado pelos autores.

Módulo 03: Teoria - Ciclo Celular

- Metodologia alternativa 4 - Elaboração de modelo didático do ciclo celular: participantes devem representar as diferentes fases do ciclo celular usando massinha. Adaptado de: http://www.biologia.seed.pr.gov.br/arquivos/File/praticas/mitose_massinha.pdf

Módulo 04: Teoria - A primeira Lei de Mendel e as suas extensões

- Metodologia alternativa 5 - Elaboração de modelo didático usando miçangas coloridas e as diferentes interações alélicas: participantes devem representar os diferentes tipos de interação alélica utilizando miçangas e círculos coloridos. Elaborada pelos autores.

Módulo 05: Teoria - Segunda Lei de Mendel e Ligação

- Metodologia alternativa 6 - Realização de jogo Memogene: participantes devem associar termos a suas definições em um jogo da memória e resolver problemas da $2^{\mathrm{a}}$ Lei e a ligação para dobrar a pontuação. Elaborado pelos autores.

Módulo 06: Teoria - Ligada ao Sexo, Heredogramas e Mutações Cromossômicas. 
- Metodologia alternativa 7 - Realização de bingo dos Cromossomos Sexuais: sortear o genótipo de vários indivíduos para características de herança ligada ao sexo usando feijões coloridos. Anotar os genótipos e comparar as proporções de homens e mulheres afetados. Elaborada pelos autores;

- Metodologia alternativa 8 - Realização de atividade montando cariótipos: participantes devem recortar e associar os 23 pares de cromossomos humanos para montagem do cariograma. Identificar o sexo do indivíduo e a existência de anomalia. Replicada de: https://bgnaescola.files.wordpress.com/2009/12/cariotipo.pdf.

Módulo 07: Teoria - Interação Gênica e Tópicos Atuais de Genética

- Metodologia alternativa 9 - Realização de Seminário sobre a Interação Gênica: em grupos, os participantes devem elaborar cartazes referentes a um dos tipos de Interação Gênica e apresentar para a turma. Elaborado pelos autores.

Módulo 08: Teoria - Evolução

- Metodologia alternativa 10 - Realização de bingo Evolutivo: participantes devem sortear o genótipo de 100 indivíduos usando diferentes quantidades de feijões brancos e pretos, para observar o efeito de diferentes fatores evolutivos na frequência alélica de uma população. Elaborada pelos autores.

Módulo 09: Teoria - Introdução à Herança Poligênica e Retomada sobre os diferentes Padrões de Herança. Módulo 10:

- Feedback do curso - Os docentes avaliaram anonimamente o curso e as metodologias alternativas;

- Questionário Final - Professores responderam novamente ao questionário aplicado na aula 1.

Fonte: Elaborado pelos autores (2021)

Conforme observado no Quadro 1, o curso "Desenrolando a Genética" buscou retomar a teoria dos principais conteúdos de Genética ministrados no Ensino Médio e apresentou diferentes tipos de metodologias alternativas de ensino de Genética para os professores. Tal estratégia visa minimizar as defasagens teórico-práticas reportadas pelos docentes.

O curso "Desenrolando a Genética" foi concluído por 33 professores, sendo $82 \%(n=27)$ do sexo feminino e $18 \%(n=6)$ do sexo masculino. Entre os docentes, $73 \%(n=24)$ trabalhavam apenas em escolas púbicas, $15 \%(\mathrm{n}=5)$ apenas em escolas particulares, $3 \%(\mathrm{n}=1)$ trabalhava nos dois tipos de escola, enquanto $9 \%(\mathrm{n}=3)$ não estavam lecionando no momento. O tempo médio de docência era de 14,7 anos, sendo o tempo mínimo um semestre e o máximo 30 anos.

A avaliação da efetividade e de eventuais limitações deste curso como proposta para minimizar as dificuldades no processo de ensino-aprendizagem de Genética foram mensuradas por três parâmetros. O primeiro consistiu na comparação das respostas dadas pelos professores aos questionários básicos de Genética (Quadro 2) aplicados no início e no fim do curso. 
Quadro 2 - Questionário básico de Genética aplicado ao início e ao final do curso "Desenrolando a Genética".

\begin{tabular}{|l|}
\hline \multicolumn{1}{|c|}{ Questionário comparativo - Genética Básica } \\
\hline 1 - Conceitue código genético e genoma. \\
\hline 2 - Por que os gametas são haploides? \\
\hline 3 - Qual a relação entre a primeira lei e a meiose? \\
\hline 4 - Conceitue alelo e gene \\
\hline 5 - Conceitue Dominância, Recessividade Dominância Incompleta, Codominância \\
\hline $\begin{array}{l}6 \text { - Na família de Bianca, seu pai e seu tio materno são hemofílicos, enquanto seu pai e seu irmão são carecas. É } \\
\text { possível que Bianca seja hemofílica ou careca? }\end{array}$ \\
\hline 7 - Todas as características genéticas são transmitidas igualmente? Se não, exemplifique diferentes padrões. \\
\hline 8 - Qual a utilidade de um heredograma? Indicar o significado dos diferentes símbolos. \\
\hline $\begin{array}{l}\text { 9 - Qual teorema afirma que: "Se nenhum fator evolutivo atuar sobre uma população, a frequência de seus alelos } \\
\text { permanece inalterada ao longo das gerações"? }\end{array}$ \\
\hline 10 - Descreva como você se sente para preparar e ministrar aulas que incluam conteúdos de Genética. \\
\hline
\end{tabular}

Fonte: Elaborado pelos autores (2018)

A correção das nove primeiras questões desses questionários considerou o seguinte critério: resposta inadequada (0.00); resposta predominantemente inadequada (0.25); resposta incompleta (0.50); resposta predominantemente adequada (0.75) ou resposta adequada (1.00). A comparação das respostas dadas por um mesmo professor nos dois questionários foi realizada pelo teste estatístico de Wilcoxon $(\mathrm{p}<0,05)$ para duas amostras dependentes. As respostas dadas à questão 10 foram registradas e comparadas como um parâmetro qualitativo. Os professores responderam aos questionários em sala de aula, sem a possibilidade de qualquer consulta.

O segundo parâmetro consistiu em um formulário anônimo, respondido em sala de aula no último encontro e usado para obter o feedback dos professores. Nesse formulário, eles atribuíram uma nota de 0 a 10 e puderam escrever elogios, críticas e sugestões para cada uma das dez metodologias alternativas aplicadas (Apêndice C). As notas dadas pelos docentes foram somadas, tabuladas no Excel e usadas para calcular a média de aprovação de cada atividade (parâmetro quantitativo). Os comentários feitos pelos professores foram registrados no Word e servirão para adequações futuras das atividades (parâmetro qualitativo).

O terceiro parâmetro consistiu no preenchimento de um formulário final (Apêndice D) pelo Google Forms. Os professores que participaram do curso foram contactados por e-mail, um ano e meio após a conclusão do curso para verificarmos como estava a utilização das metodologias alternativas por esses docentes. Eles não foram avisados durante a realização do curso sobre esse formulário final para evitar que utilizassem as metodologias alternativas por essa razão. Neste formulário, os docentes deveriam relatar com que frequência utilizaram as metodologias alternativas apresentadas no curso (frequentemente, algumas vezes, poucas vezes, uma vez, não utilizei). Isso permitiu aos autores observar se as metodologias apresentadas durante o curso estavam sendo utilizadas por esses professores nas escolas.

\section{Resultados e Discussão}

Todos os 1140 alunos responderam aos questionários sem deixar nenhuma questão em branco. O interesse médio dos alunos pelos temas de Genética foi de 6,10 pontos, em uma escala de zero a dez. Em relação ao grau de dificuldade dessa temática, 31\% (n=353) deles consideram difícil ou muito difícil, $60 \%(\mathrm{n}=684)$ regular e apenas $9 \%(\mathrm{n}=103)$ fácil. Além disso, os alunos indicaram os principais fatores que comprometiam seu aprendizado (Figura 1). 
Figura 1 - Fatores que influenciam na dificuldade dos alunos aprenderem Genética.

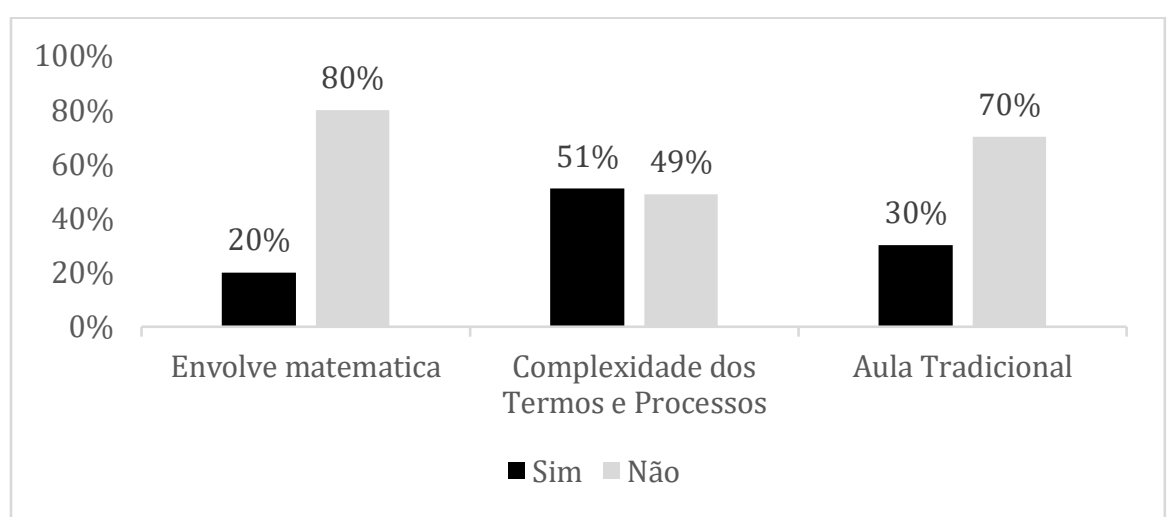

Fonte: Elaborado pelos autores (2021)

Conforme observado na Figura 1, a complexidade dos termos e processos é o principal fator responsável pelas dificuldades de aprendizado em Genética, citada por $51 \%(n=581)$ dos alunos. A aula tradicional (expositiva) foi marcada por $30 \%(\mathrm{n}=342)$ deles, e o envolvimento da matemática por $20 \%(\mathrm{n}=228)$. Estudos realizados nos Estados Unidos e na Holanda já haviam identificado a complexidade dos termos e processos e o envolvimento da matemática como fatores que podem comprometer o aprendizado de Genética (KNIPPELS; WAARLO; BOERSMA, 2005; DOUGHERTY et al., 2011).

De acordo com os autores supracitados, muitas vezes os conteúdos de Genética são ensinados de forma abstrata, ou seja, sem conexão com a realidade do aluno ou com algo que o estudante seja capaz de transformar em um objeto ou lembrança. Nesse contexto, o aluno apenas memoriza muitos termos, o que inclui conceitos que são escritos de forma semelhante, mas possuem significado diferente (ex. heterozigoto, heterose; fenótipo e genótipo). Nesse sentido, Durbano et al. (2008) acrescentam que muitos alunos terminam o ensino médio entendendo genética como "A/a", sem sequer compreender aspectos básicos da hereditariedade. Adicionalmente, Shaw et. al (2008) acrescentam que as concepções prévias e equivocadas dos estudantes sobre alguns conceitos de Genética, obtidas em casa e nos meios de comunicação, corroboram para as dificuldades dos estudantes com a terminologia da Genética.

Em relação ao envolvimento da matemática, Dougherty et al. (2011) consideram essa dificuldade natural, pois muitos estudantes possuem dificuldades em matemática, de modo que a resolução de problemas e o cálculo da probabilidade dificultam o aprendizado de Genética. Marshall e Duran (2018) acrescentam que muitos cursos de graduação de Biologia falham ao conectar a ciência e a matemática, formando professores que não estão bem preparados para ensinar Genética. Tal dificuldade fica evidente quando Belmiro e Barros (2017) verificam que 75\% dos estudantes participantes de seu estudo sentiram dificuldades para solucionar uma questão de Genética que envolvia conceitos básicos de probabilidade.

Em contrapartida, os artigos supracitados não fizeram menção às aulas tradicionais como um obstáculo para aprender Genética. Uma possível explicação é que o uso de metodologias alternativas de ensino em Genética é amplamente reportado em países desenvolvidos como os Estados Unidos e a Holanda (TSUI; TREAGUSH, 2007; BREAKLEY et al., 2008; STARBEK; ERJAVEC; PEKLAJ, 2010). Essa teoria é corroborada pelo estudo de Haambokoma (2007), realizado na Zâmbia, um país em desenvolvimento que identificou a falta de recursos de ensino e o uso de explicações inadequadas (a explicação dada pelo professor contém falhas conceituais e é insuficiente para a compreensão do conteúdo) como obstáculos para aprender Genética. 
Nesse sentido, como os nossos resultados indicaram a complexidade dos termos como principal obstáculo para aprender Genética, assim como os trabalhos mencionados anteriormente, acreditamos que é natural que um maior número de alunos reconheça este fator como um obstáculo para a aprendizagem de Genética. Isso pode estar associado ao fato de novos termos serem apresentados aos alunos durante todo o processo de ensino-aprendizagem de Genética. Além disso, quando o aluno começa a ter contato com a probabilidade e com os cruzamentos genéticos, a dificuldade relacionada à terminologia já é existente, desde o seu primeiro contato com essa temática. A influência das aulas tradicionais na dificuldade dos alunos aprenderem Genética, levantada por este estudo e por Haambokoma (2007) precisa ser melhor compreendida e será melhor discutida a partir dos resultados das próximas questões. Nós acreditamos que o uso da metodologia tradicional nas aulas de Genética pode aumentar o número de alunos com dificuldades relacionadas à complexidade dos termos e processos.

Em relação à influência das aulas tradicionais (aulas expositivas; sem o uso de recursos didáticos além do quadro, giz e livro didático) no processo de ensino-aprendizagem de Genética, 53\% ( $\mathrm{n}=604)$ dos estudantes reportaram nunca ter tido acesso a metodologias alternativas de ensino nas aulas de Genética. Dentre os alunos que já tiveram acesso às metodologias alternativas, a maioria teve acesso somente por meio de vídeos ou imagens, trazidos e projetados em sala de aula pelo professor. Isso sugere que outros tipos de recursos alternativos, como aulas práticas, modelos didáticos e jogos quase não são utilizados pelos professores. Entretanto, estas metodologias possuem grande aceitação entre os estudantes, pois 99,5\% ( $\mathrm{n}=1134)$ deles assinalaram pelo menos um dos tipos de metodologias alternativas de ensino como forma de aumentar seu interesse em aprender Genética (Tabela 1).

Tabela 1 - Número e percentual de alunos interessados em cada tipo de metodologia alternativa de ensino

\begin{tabular}{c|c|c}
\hline Metodologia sugerida & \% de alunos interessados & (n) alunos interessados \\
\hline Aula prática & $73,95 \%$ & 843 \\
Aula de campo & $48,77 \%$ & 556 \\
Músicas e paródias & $21,05 \%$ & 240 \\
Vídeos e imagens & $37,81 \%$ & 431 \\
Jogos & $23,25 \%$ & 265 \\
Modelos didáticos & $23,86 \%$ & 272 \\
Visita a universidade & $67,46 \%$ & 769 \\
Interessado em pelo menos um dos tipos & $99,50 \%$ & 1134 \\
\hline
\end{tabular}

Fonte: Elaborado pelos autores (2021)

Os dados apresentados pela tabela 1 revelam que as metodologias que despertam o interesse de um maior número de alunos são: aula prática, visita à universidade e aula de campo. Essas metodologias possuem em comum o fato de permitirem que o aluno vivencie de forma real a construção do seu conhecimento, aprendendo a partir da observação e da experimentação. Souza (2014) considera essas ferramentas como potencializadoras do ensino de Biologia, pois o contato com o laboratório, com a natureza e com a universidade aproxima o aluno do conhecimento científico. $\mathrm{O}$ uso de jogos e modelos didáticos, citados por pouco mais de $23 \%$ dos estudantes também tem se mostrado uma ferramenta de ensino valiosa no processo de ensino-aprendizagem de Genética, especialmente quando o aluno participa da construção do material (BREAKLEY et al., 2008; BISSOLI; SANTOS; CONDE, 2018). Além disso, Chen, Moran e Gardner (2009) acrescentam que os alunos apresentam diferentes tipos de inteligências e formas de aprender, o que por si só justifica a importância de não se limitar à metodologia tradicional de ensino, e a necessidade de utilizar diferentes metodologias e recursos didáticos. Bissoli, Santos e Conde (2018) ponderam que na educação básica brasileira ainda há um grande 
predomínio de aulas expositivas. Isso pode explicar o fato de que 30\% ( $\mathrm{n}=342)$ dos alunos mencionaram as aulas tradicionais como um dificultador na aprendizagem de Genética.

Todos os questionários respondidos pelos professores foram respondidos integralmente. O grau de interesse médio por Genética atribuído pelos docentes foi de 8,5 em uma escala de 0 a 10. Além disso, 35\% $(\mathrm{n}=18)$ dos professores afirmaram nunca terem utilizado nenhum tipo de metodologia alternativa de ensino em suas aulas de Genética, enquanto 88\% ( $\mathrm{n}=46)$ disseram que teriam interesse em formação continuada na área. A figura 2 indica o percentual de professores que possuem alguma defasagem em relação aos conteúdos de Genética.

Figura 2 - Percentual de docentes que possuem defasagem teórica e/ou prática em Genética.

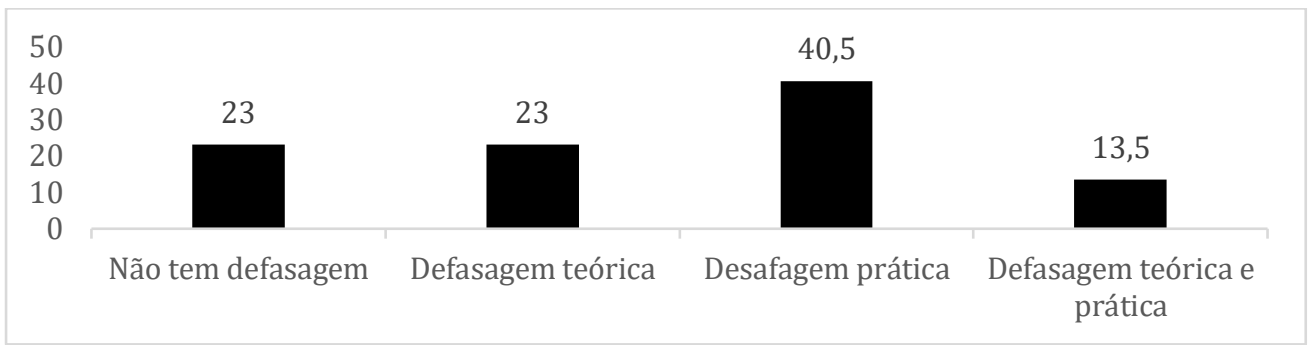

Fonte: Elaborado pelos autores (2021)

A figura 2 mostra que 54\% $(n=28)$ dos professores têm defasagem prática e 36,5\% $(n=19)$ têm defasagem teórica em Genética. Esses percentuais foram obtidos somando o número de professores que afirmam ter somente um tipo dos defasagem com os $13,5 \%(n=7)$ que possuem ambos. $23 \%(\mathrm{n}=12)$ dos professores declararam não ter nenhum tipo de defasagem nesta temática. A partir desses dados, podemos observar que $77 \%(\mathrm{n}=40)$ dos professores possuem algum tipo de defasagem em Genética. Esses resultados mostram que os professores também possuem dificuldades nesta temática. Dentro desse contexto, a Figura 3 apresenta os principais obstáculos apontados pelos docentes para ensinar Genética.

Figura 3 - Fatores considerados como obstáculos para ensinar Genética.

\begin{tabular}{|c|c|c|c|c|c|c|}
\hline \multirow{2}{*}{$\begin{array}{r}100 \% \\
50 \% \\
0 \%\end{array}$} & $50 \%$ & $50 \%$ & $60 \%$ & $40 \%$ & $40 \%$ & $60 \%$ \\
\hline & \multicolumn{2}{|c|}{$\begin{array}{l}\text { Envolvimento da } \\
\text { matemática }\end{array}$} & \multicolumn{2}{|c|}{$\begin{array}{c}\text { Complexidade dos Termos } \\
\text { e Processos }\end{array}$} & \multicolumn{2}{|c|}{$\begin{array}{c}\text { Pouco tempo para preparar } \\
\text { aulas variadas }\end{array}$} \\
\hline
\end{tabular}

Fonte: Elaborado pelos autores (2021)

Os dados apresentados pelas figuras 2 e 3 mostram que a maioria dos docentes (77\%) possui algum tipo de defasagem e/ou dificuldade em Genética. Essas dificuldades podem começar a ser compreendidas a partir do envolvimento da matemática, pois metade dos professores consideram este fator como um dificultador para ensinar Genética. Esses dados corroboram com o estudo de Marshall e Duran (2018), que ponderam que as dificuldades associadas à matemática estão relacionadas com as dificuldades que profissionais das áreas biológicas possuem com os cálculos, e com o fato de muitos cursos superiores de Biologia não fazem uma boa conexão entre a Genética e a matemática. 
Os obstáculos matemáticos enfrentados pelos docentes acabam prejudicando a aprendizagem teórica dos conteúdos, o que pode ser mensurado a partir dos $60 \%(n=31)$ de professores que possuem dificuldades relacionadas à complexidade dos termos e processos. Esse cenário causa preocupação, pois Cebesoy e Ozketin (2017) discutem que a falta de um bom domínio teórico do conteúdo prejudica que o docente prepare aulas mais dinâmicas e bem estruturadas, o que conforme relatado por este estudo impactará na defasagem prática em Genética, observada em 54\% ( $\mathrm{n}=28)$ dos professores. Haambokoma (2007) e Belmiro e Barros (2017) ressaltam a importância de acrescentar que a baixa disponibilidade de recursos e o pouco tempo que os professores têm para preparar suas aulas não favorecem que eles enfrentem sua defasagem teórico-prática em Genética sozinhos. Nesse sentido, a baixa disponibilidade de recursos e materiais em algumas escolas faz com que muitas vezes os professores precisem arcar com os gastos para a realização de atividades alternativas, o que também pode limitar uma realização mais frequente dessas atividades.

A primeira análise de regressão múltipla revelou que o grau de dificuldade em Genética reportado pelos alunos participantes da pesquisa é influenciado significativamente pela sua nota de interesse em Genética ( $\mathrm{p}<0,0001)$, pela complexidade dos termos e processos $(\mathrm{p}<0,0001)$, pelo envolvimento da matemática $(\mathrm{p}<0,0001)$, pelas aulas tradicionais, consideradas pouco dinâmicas $(\mathrm{p}=0,0043)$ e pelo interesse do seu professor por Genética $(\mathrm{p}=0,0133)$. As variáveis sexo do aluno $(p=0,93)$ e escola $(p=0,21)$ não foram estatisticamente significantes. Dessa forma, com os resultados obtidos nessa análise estatística corroboramos com os dados já citados de estudos realizados em outros países que apontavam para a influência desses fatores na dificuldade de aprendizado dos estudantes em Genética (KNIPPELS; WAARLO; BOERSMA, 2005; HAAMBOKOMA, 2007; DOUGHERTY et al., 2011). Os baixos valores de p sugerem que essa influência é muito forte. Além disso, esta análise mostrou que o grau de dificuldade e a nota de interesse do aluno por Genética estão fortemente relacionados ( $\mathrm{p}<0,0001$ ) (Figura 4).

Figura 4 - Relação entre o grau de dificuldade e a nota de interesse por Genética dos alunos.

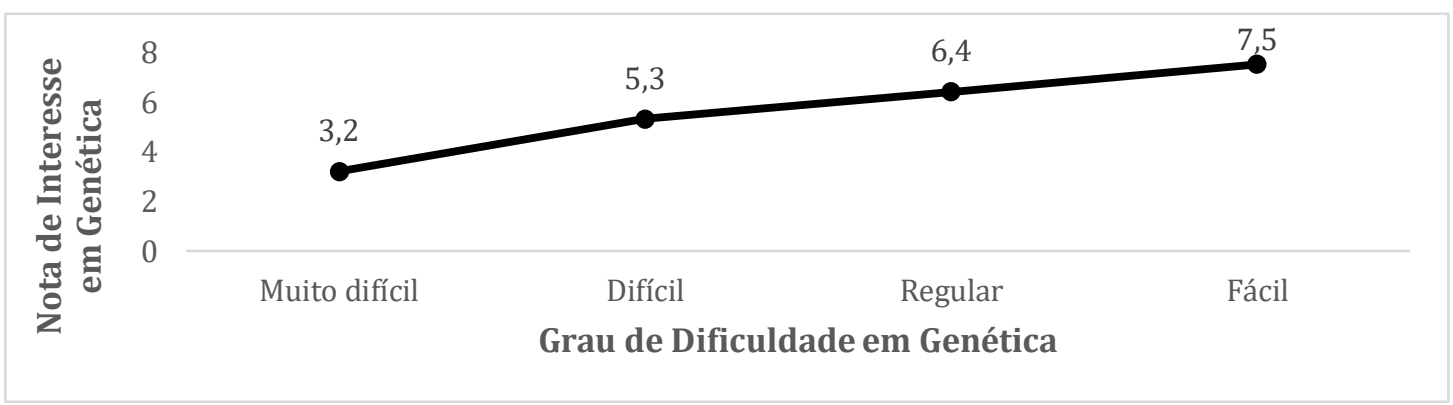

Fonte: Elaborado pelos autores (2021)

A partir da figura 4 podemos observar que a nota de interesse por Genética reportada pelos alunos aumenta conforme o grau de dificuldade reportado diminui. Ao considerarmos todos os 1140 alunos, verificamos que a nota média de interesse em Genética foi de 6,10 pontos. No entanto, entre os alunos que consideram a temática muito difícil, a nota média de interesse cai para 3,20 pontos. Em contrapartida, entre os estudantes que consideram a temática fácil, a nota média de interesse aumenta para 7,50 pontos. A percepção dessa relação é importante, pois sugere que se trabalharmos com alternativas para diminuir as dificuldades dos alunos, será possível aumentar seu interesse e consequentemente o aprendizado dos estudantes nesta área. Esses dados mostram a importância de minimizar as dificuldades dos estudantes em Genética, cuja existência foi reportada inicialmente por Bahar, Johnstone e Hansell (2000) que 


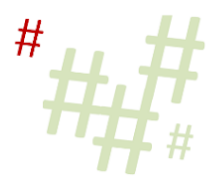

identificaram que os conteúdos de Genética foram apontados como os mais complexos de aprender por estudantes escoceses. Além disso, Marques, Persich e Neto (2017) acrescentam que os alunos com dificuldade tendem a não se interessar por este conteúdo e a relação entre desinteresse e dificuldade cresce à medida que o professor não enfrenta esse problema.

O enfrentamento das dificuldades de aprendizado dos estudantes é um caminho para melhorar o processo de ensino-aprendizagem em Genética. Atualmente, a abordagem de ensino tem um enfoque muito conteudista, e no caso específico da Genética, muitos temas para serem ensinados em pouco tempo (HAAMBOKOMA, 2007; BELMIRO; BARROS, 2017). Nesse contexto, alguns países já superaram essa abordagem conteudista e passaram a priorizar a conexão dos conteúdos ensinados com a realidade do aluno (DOUGHERTY et al., 2011). No Brasil, uma maior atenção à conexão dos conteúdos com a realidade dos alunos tem sido dada a partir da nova BNCC (MEC, 2018). No entanto, ainda é necessário buscar estratégias que aumentem o uso de metodologias alternativas de ensino pelos docentes. Bissoli, Santos e Conde (2018) reforçam que uma melhor conexão dos conteúdos com a realidade do aluno pode ser feita a partir da utilização de metodologias alternativas e ativas, dando protagonismo ao estudante no seu processo de aprendizagem. Nesse sentido, a capacitação dos professores de biologia na temática de Genética é importante e pode ser feita por meio de formação continuada.

A segunda análise de regressão múltipla mostrou que a baixa utilização de métodos alternativos no ensino de Genética pelos professores está associada com: o seu interesse por Genética ( $\mathrm{p}<0,0001)$; a sua defasagem teórica $(\mathrm{p}=0,0455)$; a sua defasagem prática $(\mathrm{p}=0,0043)$; o envolvimento da matemática ( $\mathrm{p}<0,0001)$; o pouco tempo para preparar as aulas diversificadas $(\mathrm{p}=0,0240)$; e com a sua formação universitária, que pode ser considerada deficiente na área $(\mathrm{p}=0,0005)$. Estes dados reforçam a existência de dificuldades por parte dos docentes em Genética (HAAMBOKOMA, 2007; MARSHALL; DURAN, 2018), já discutidas anteriormente. Diante das evidências de que a dificuldade e o desinteresse por Genética estão relacionados e de que parte dos professores possui defasagens teórico-práticas nesta área, fica evidente a importância da realização de cursos de formação continuada em Genética.

Acreditamos que com a redução das dificuldades teóricas e práticas, os docentes serão capazes de preparar aulas mais dinâmicas, minimizando o impacto causado pela baixa utilização de metodologias alternativas de ensino em Genética. A utilização da metodologia tradicional de ensino (aula expositiva) tem sido frequentemente criticada. Autores como Chen, Moran e Gardner (2009); Belmiro e Barros (2017) e Bissoli, Santos e Conde (2018) ponderam que a metodologia tradicional é pouco eficaz para o ensino de conteúdos abstratos, ou seja, que acontecem em nível microscópico, como os de Genética. Além disso, podemos apontar que as dificuldades de ensino-aprendizagem de Genética são contínuas, passando dos professores aos alunos por gerações. Isso acontece porque estudantes e docentes perdem o interesse por esta temática e acabam não enfrentando as suas dificuldades.

Nesse contexto, Bissoli, Santos e Conde (2018) apontam o uso das metodologias alternativas e ativas como possível caminho para diminuir as dificuldades de aprendizado de Genética. Não é possível ensinar Genética sem o envolvimento da matemática ou sem apresentar os seus conceitos. No entanto, todos os resultados apresentados até aqui sugerem que o enfrentamento das defasagens teórico-práticas pelos docentes e o uso de metodologias alternativas de ensino podem minimizar as dificuldades existentes no processo de ensinoaprendizagem de Genética, reforçando a importância da formação continuada nesta área.

Diante desse contexto, o curso "Desenrolando a Genética 2018" foi realizado. Todos os 33 docentes participantes do curso responderam a todas as questões presentes nos questionários de Genética Básica, aplicados no início e no final do curso. A partir da comparação das notas 
obtidas pelos participantes nas respostas dadas a esses questionários foi possível perceber que o curso contribuiu para a formação continuada dos professores (Tabela 2).

Tabela 2 - Comparativo entre as médias obtidas a partir dos questionários inicial e final de Genética Básica.

\begin{tabular}{clccc}
\hline Questão & \multicolumn{1}{c}{ Conteúdo abordado } & M \pm DP início & M \pm DP final & P \\
\hline 1 & Conceitos Básicos & $0,31 \pm 0,34$ & $0,69 \pm 0,34$ & $0,00^{*}$ \\
2 & Divisão Celular & $0,45 \pm 0,36$ & $0,59 \pm 0,35$ & $0,02^{*}$ \\
3 & Divisão Celular e $1^{a}$ Lei & $0,31 \pm 0,25$ & $0,61 \pm 0,38$ & $0,00^{*}$ \\
4 & Conceitos Básicos & $0,33 \pm 0,30$ & $0,63 \pm 0,34$ & $0,00^{*}$ \\
5 & Primeira Lei e Extensões & $0,45 \pm 0,25$ & $0,77 \pm 0,24$ & $0,00^{*}$ \\
6 & Herança Ligada ao Sexo & $0,32 \pm 0,27$ & $0,45 \pm 0,36$ & 0,06 \\
7 & Padrões de Herança & $0,33 \pm 0,25$ & $0,52 \pm 0,26$ & $0,00^{*}$ \\
8 & Heredograma & $0,71 \pm 0,28$ & $0,92 \pm 0,17$ & $0,00^{*}$ \\
9 & Genética de Populações & $0,20 \pm 0,36$ & $0,45 \pm 0,50$ & $0,00^{*}$ \\
\hline
\end{tabular}

Legenda: M \pm DP: Média \pm Desvio Padrão. Fonte: Elaborada pelos autores (2021).

Os resultados apresentados pela tabela 2 mostram que antes de participarem do curso, os professores tiveram um baixo desempenho (média inferior a 0,5 ) em oito das noves questões. As baixas médias obtidas no questionário inicial podem estar relacionadas com as dificuldades de parte dos docentes participantes do curso nos conteúdos de Genética, o que pode indicar que os professores não tiveram uma boa formação universitária nesta temática. O desempenho dos professores na questão oito (heredogramas) chamou a atenção positivamente. Esta questão apresentou as maiores médias antes e após a realização do curso. Entre as possíveis explicações para esse melhor desempenho está a construção de heredogramas em aulas de Genética no ensino superior, que é uma tarefa relativamente comum, e que confere protagonismo aos alunos. Dessa forma, acreditamos que essa é uma possível explicação para o melhor desempenho dos participantes do curso nesta questão e que reforça a importância das metodologias alternativas e ativas no processo de ensino-aprendizagem de Genética e de cursos de formação continuada nesta área. Ao adquirem um maior domínio do conteúdo, os professores podem ministrar aulas mais preparadas, contribuindo para o aprendizado dos estudantes.

Além disso, os resultados da tabela 2 indicam que os professores melhoraram o desempenho em oito das nove questões. A única questão em que não houve uma melhora significativa foi a questão seis (herança ligada ao sexo). Nós acreditamos que os professores tiveram dificuldade em compreender o enunciando desta questão, uma vez que ela envolvia duas características (hemofilia e calvície) e membros da família pelos lados paterno e materno. Dessa forma, estes dados sugerem que a participação no curso ajudou a diminuir as dificuldades apresentadas pelos docentes em Genética. A importância da realização de um curso de formação continuada em Genética já havia sido demonstrada pelo estudo de Marques, Persich e Neto (2017), que relataram o ganho de conhecimento pelos professores participantes de um curso de formação voltado para a biotecnologia genética. De acordo com os autores, a participação no curso abriu novas perspectivas para os docentes, sendo positiva do ponto de vista teórico e prático. A contribuição do curso "Desenrolando a Genética" fica ainda mais evidente quando analisamos as respostas dadas pelos docentes na décima questão, que pedia para que eles descreverem a sensação de preparar uma aula com conteúdos de Genética:

Antes do curso: Sinto mais dificuldade do que em outros conteúdos, mas dou aula há muitos anos, então vou me virando. Depois do curso: Muito preparada. Compreendi melhor os conteúdos, e a minha dificuldade em Genética diminuiu. Já utilizei algumas propostas de metodologias alternativas em sala de aula e foi ótimo. (Professor 10). 
Antes do curso: Mais ou menos. Preciso revisar o conteúdo toda vez que vou ministrálo, então não sobra tempo para preparar nada de diferente. Depois do curso: Bem preparada. A revisão teórica foi ótima e as metodologias alternativas trouxeram outro horizonte para minhas aulas (Professor 13).

Antes do curso: Ruim. Já é desafiador ensinar um tema que eu domino. Portanto, ensinar um tema que tenho dificuldades, torna-se praticamente impossível. O tempo para preparar as aulas é curto, e o tempo que eu levo para preparar uma aula de Genética é quatro vezes maior que o normal. Então, eu opto por priorizar o preparo das outras aulas. Depois do curso: Acho que estou preparado. O curso sanou várias de minhas dúvidas e ao apresentar as metodologias alternativas de ensino, me disponibilizou algo pronto, que posso utilizar, sem gastar muito tempo preparando. Porém, preciso enfrentar as limitações da escola e gastar do meu dinheiro para desenvolver essas atividades (Professor 25).

As respostas transcritas acima evidenciam que a participação no curso foi enriquecedora para os professores, permitindo o preparo de aulas mais dinâmicas a partir da utilização de metodologias alternativas de ensino. Além disso, essas respostas indicam que as defasagens teórica e prática, identificadas como responsáveis pelas dificuldades do professor em Genética, foram minimizadas, uma vez que os docentes fizeram elogios à revisão teórica dos conteúdos e à apresentação das metodologias alternativas de ensino de Genética. Essas respostas representam o comparativo entre o antes e o depois da realização do curso de alguns professores. De modo a ter uma visão geral de todas as respostas dadas à essa questão, nós utilizamos uma nuvem de palavras para apresentar as palavras mais utilizadas nas respostas dadas à essa questão antes e depois da realização do curso (Figura 5).

Figura 5 - Nuvem de palavras com as respostas dos professores, antes e depois do curso "Desenrolando a Genética” sobre como eles se sentia para preparar e ministrar aulas de Génetica.

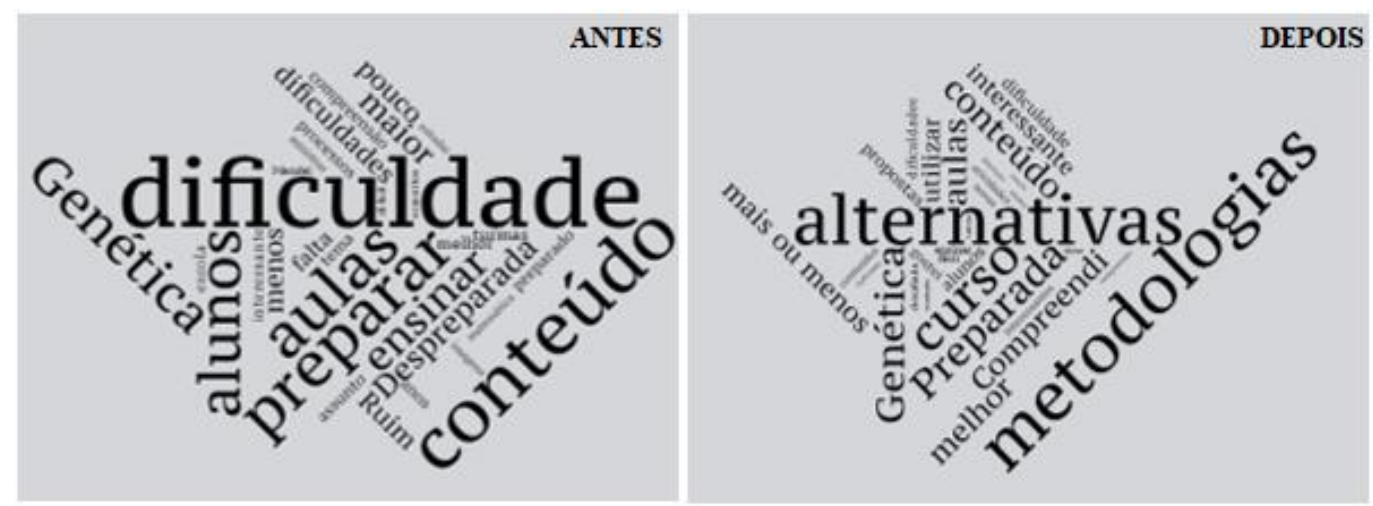

Fonte: Elaborado pelos autores (2021)

A partir das nuvens de palavras, apresentadas na figura 5 verificou-se que as palavras mais utilizadas antes da realização do curso foram: dificuldade, Genética, aulas, preparar, ensinar, conteúdo, alunos e despreparada. Após a realização do curso, as palavras mais utilizadas foram: alternativas, metodologias, Genética, mais ou menos, curso, preparada, compreendi, melhor. A partir da análise comparativa entre as nuvens de palavras percebemos que as palavras dificuldade e despreparada - elementos negativos em destaque na primeira nuvem de palavra - quase não foram mencionadas após a realização do curso. A diminuição no uso desses termos e a ampla utilização de palavras que estavam diretamente relacionadas com os propósitos do curso - como metodologia, alternativa, curso, preparada - são indicativos de que o curso "Desenrolando a Genética" foi produtivo para os docentes. 


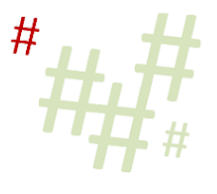

Dessa forma, os parâmetros quantitativos e qualitativos analisados através da comparação das respostas dadas ao questionário básico de Genética, aplicado ao início e ao final do curso, indicam a efetividade do curso. Além dos questionários básicos, todos os professores participantes responderam ao final do curso a um formulário de avaliação das metodologias alternativas apresentadas a eles durante o curso.

A análise quantitativa desses formulários mostrou que todas as metodologias alternativas atingiram uma média superior a 8 pontos, sendo, portanto, bem avaliadas pelos docentes participantes do curso (Tabela 3).

Tabela 3 - Média de aprovação de cada proposta de metodologia alternativa para o ensino de Genética.

\begin{tabular}{c|l|c}
\hline Proposta & \multicolumn{1}{|c}{ Metodologia Alternativa } & Média \\
\hline 1 & Dicionário de Biologia & 8,82 \\
2 & Modelo Didático do DNA com haste e miçangas & 9,21 \\
3 & Jogo da Síntese Proteica & 9,18 \\
4 & Modelo didático do Ciclo Celular & 9,14 \\
5 & Representando genótipos e fenótipos - Interações Alélicas & 9,27 \\
6 & Jogo: Memogene - 2 Lei de Mendel e Ligação & 8,05 \\
7 & Bingo dos Cromossomos Sexuais & 9,04 \\
8 & Montando Cariótipos & 9,29 \\
9 & Interagindo com a Interação Gênica & 8,97 \\
10 & Bingo Evolutivo & 9,24 \\
\hline
\end{tabular}

Fonte: Elaborada pelos autores (2021)

A tabela 3 mostra que as três propostas que mais agradaram aos professores foram "Montando Cariótipos", "Representando genótipos e fenótipos - Interações Alélicas", e o "Bingo Evolutivo". Apenas três propostas obtiveram média inferior a nove pontos: "Interagindo com a Interação Gênica", "Dicionário de Biologia", e "Memogene", o que enfatiza a aprovação destas metodologias. A utilização exitosa das metodologias alternativas no ensino de Genética tem sido reportada pelo mundo. Nesse sentido, Fontenele e Campos (2017) notaram uma melhora no desempenho dos alunos na compreensão de conceitos básicos de Genética após a utilização de um modelo didático relacionado a estrutura do DNA. As autoras compararam os resultados de questionários aplicados antes e após a utilização do modelo e obtiveram uma melhora de performance em 70\% das respostas. Além disso, Tsui e Treagush (2007) e Breakley et al., (2008) observaram que o uso de softwares foi uma experiência bem sucedida e aprovada pelos alunos no ensino de Genética, pois permitiu que eles observassem e simulassem diferentes situações, o que auxiliou na visualização e compreensão de processos que acontecem em nível microscópico. Nesse sentido, tanto os nossos dados quanto a literatura sugerem experiências positivas e a ampla aprovação das metodologias alternativas de ensino de Genética.

Nós defendemos que a utilização das metodologias alternativas de ensino favorece o aprendizado de um maior número de alunos, pois cada estudante aprende de uma forma. Além disso, muitos conteúdos de Genética, acontecem em nível celular e são de difícil visualização para o estudante. Dentro desse contexto, a utilização de modelos didáticos e jogos facilita a visualização e o entendimento desses conteúdos. Nosso ponto de vista corrobora com a perspectiva de Chen, Moran e Gardner (2009) acerca das inteligências múltiplas e da importância de utilizar diferentes recursos didáticos no processo de ensino-aprendizagem de qualquer conteúdo e qualquer disciplina. Os autores também entendem que cada tipo de recurso pode favorecer o aprendizado de um determinado grupo de estudantes.

Dentro dessa temática, Souza (2014) acrescenta que o ensino de Biologia pode ser facilitado a partir da utilização de metodologias alternativas, como modelos didáticos, jogos, 
aulas práticas e simuladores. De acordo com o autor, cada conteúdo permite a utilização de mais de um recurso e o docente precisa ter tempo, domínio do conteúdo, e estar preparado para a utilização desses recursos. Dessa forma, o curso "Desenrolando a Genética" contribuiu com esses três fatores. Em relação ao domínio do conteúdo, revisando teoricamente os temas de Genética que são ensinados no Ensino Médio. Além disso, as problemáticas relacionadas à falta de tempo e ao despreparo dos docentes em utilizar as metodologias alternativas também foram reduzidas, pois apresentamos aos docentes metodologias alternativas que podem ser replicadas em sala de aula. Assim, é possível dizer que o curso exerceu seu papel de formação continuada, reforçando o domínio teórico do conteúdo e preparando os professores para a utilização das metodologias alternativas nas suas aulas de Genética.

As altas médias apresentadas na Tabela 3 indicam a aprovação das atividades realizadas. No entanto, a utilização da média como um parâmetro quantitativo isolado não traz muita informação acerca dos aspectos positivos, negativos e da importância de cada uma das metodologias apresentadas. Uma melhor compreensão acerca desses aspectos pode ser observada no quadro 5, que apresenta um compilado dos principais comentários feitos pelos docentes para cada uma das metodologias alternativas de ensino de Genética apresentadas.

Quadro 5 - Críticas, elogios e sugestões feitas pelos participantes do curso, destacando os aspectos positivos (+) e negativos (-) das metodologias alternativas de ensino apresentadas.

\begin{tabular}{|c|c|}
\hline Metodologia Alternativa & Comentários realizados pelos professores participantes \\
\hline Dicionário de Genética & $\begin{array}{l}\text { + Fácil de fazer em sala, serve de ajuda para professores e alunos. } \\
\text { + Ajuda a aprender os principais termos de genética. } \\
\text { + Excelente, estou realizando com meus alunos, ajuda a aprender os termos. } \\
\text { - Acho que faltou no começo de cada aula, retomar os conceitos já listados. }\end{array}$ \\
\hline $\begin{array}{c}\text { Modelo didático DNA com } \\
\text { haste e miçangas }\end{array}$ & $\begin{array}{l}\text { + É bem didática, facilita a compreensão da estrutura do DNA. } \\
\text { + É uma forma diferente de ensinar a estrutura do DNA em sala. } \\
\text { + Atividades visuais são fundamentais para o aprendizado. } \\
\text { - O tamanho das miçangas é pequeno, usaria miçangas maiores. }\end{array}$ \\
\hline Jogo da Síntese Proteica & $\begin{array}{l}\text { + Adorei e apliquei em sala, pois se aprende um tema complicado jogando. } \\
\text { + Atividade didática, simples e eficiente - torna o tema visual. } \\
\text { + Facilita para aprender a síntese proteica e o impacto das mutações. } \\
\text { - Aumentar o tamanho dos itens para a colagem. }\end{array}$ \\
\hline $\begin{array}{l}\text { Modelo didático do ciclo } \\
\text { celular }\end{array}$ & $\begin{array}{l}\text { + Facilita o aprendizado dos principais acontecimentos de cada fase do ciclo. } \\
\text { + Muito interativa, ajuda a visualizar um conteúdo extremamente teórico. } \\
\text { - A massinha é cara e faz muita bagunça, tentaria usar outro material. } \\
\text { - Usaria uma base de papelão para fixar o material. }\end{array}$ \\
\hline $\begin{array}{l}\text { Representando genótipos e } \\
\text { fenótipos: Interações } \\
\text { Alélicas }\end{array}$ & $\begin{array}{l}\text { + Achei a melhor atividade. Fácil de aplicar, visualizar e compreender. } \\
\text { + Permite visualizar e diferenciar os tipos de herança. } \\
\text { + Auxilia a correlacionar conceitos e os tipos de expressão. } \\
\text { - As miçangas são ruins de colar, então trocaria este material por EVA. }\end{array}$ \\
\hline $\begin{array}{l}\text { Jogo - Memogene: } \\
\text { 2Lei e Ligação }\end{array}$ & $\begin{array}{l}\text { + Ajuda a relembrar alguns conceitos. } \\
\text { - Muito cansativa e complexa, reduzir o número de cartas. } \\
\text { - Não facilita a compreensão matemática destes conteúdos. } \\
\text { - Separar a parte da memória da parte de solução dos problemas. }\end{array}$ \\
\hline $\begin{array}{c}\text { Bingo dos cromossomos } \\
\text { sexuais }\end{array}$ & $\begin{array}{l}\text { + Atividade fácil, prática e econômica, boa para fazer em sala de aula. } \\
\text { + Permite compreender as diferenças entre as frequências observadas entre } \\
\text { homens e mulheres em algumas doenças. } \\
\text { + Fiz com meus alunos e eles adoraram e aprenderam com mais facilidade. } \\
\text { - Trocaria os feijões por botões coloridos com mesmo tamanho. }\end{array}$ \\
\hline Montando cariótipos & $\begin{array}{l}\text { + Atividade visual, interessante, fácil de aplicar e compreender. } \\
\text { + Meus alunos gostaram muito dessa atividade. } \\
\text { - Aumentar o tamanho dos cromossomos e fazer em cartolina. } \\
\text { - Acrescentaria uma pesquisa e discussão sobre síndromes. }\end{array}$ \\
\hline
\end{tabular}




\begin{tabular}{|c|l|}
\hline $\begin{array}{c}\text { Interagindo com a Interação } \\
\text { Gênica }\end{array}$ & $\begin{array}{l}\text { + Proposta bem didática, faz com que os alunos participem ativamente. } \\
\text { + Contribui para visualizar os diferentes tipos de interação Gênica. }\end{array}$ \\
& $\begin{array}{c}\text { - Acho que cada grupo poderia fazer cartazes sobre dois tipos diferentes de } \\
\text { Interação Gênica, para visualizar melhor as diferenças entre elas. }\end{array}$ \\
\hline Bingo Evolutivo & + Permite a compreensão do funcionamento de uma população e dos aspectos \\
& evolutivos relacionados a ela. \\
& + A utilização de um roteiro permite que os alunos executem a atividade \\
& sozinhos e compreendam um tema complexo brincando. \\
& - Substituir o material. Usaria copos menores e botões coloridos para o sorteio. \\
\hline
\end{tabular}

Fonte: Elaborada pelos autores (2021)

A partir das informações apresentadas pelo quadro 5, percebemos que de forma geral os professores classificaram as metodologias alternativas utilizadas como eficientes, simples, econômicas e didáticas. Os docentes também relataram que elas facilitaram a compreensão de conteúdos e permitiram que os alunos aprendessem genética. Além disso, eles relataram que os aspectos visuais presentes nas atividades facilitaram a visualização de processos e conteúdos que antes eram meramente teóricos. Os professores também apontaram algumas sugestões que foram interpretadas como pontos a serem melhorados nas atividades, como a substituição de alguns materiais (ex. miçangas por EVA, feijões por botões) de modo a adaptar a realização da atividade em suas escolas. Por fim, parte dos docentes $(n=11,33 \%)$ relataram experiências positivas utilizando pelo menos uma dessas alternativas metodologias com seus alunos antes mesmo do final do curso. De acordo com esses docentes, a motivação e o interesse dos estudantes foram as principais mudanças notadas em sala de aula. Dessa forma, esses dados corroboram as altas médias obtidas por essas atividades (Tabela 3) e com o que já foi relatado pela literatura em outros países, nos quais as metodologias alternativas no processo de ensinoaprendizagem são amplamente utilizadas e aumentam o interesse e a compreensão dos alunos, favorecendo o seu aprendizado (TSUI; TREAGUSH, 2007; BREAKLEY et al., 2008).

Os relatos apresentados no parágrafo acima são mais um indicativo da efetividade do curso, uma vez que alguns professores replicaram essas atividades em sala de aula. Dessa forma, é possível destacar a importância da realização de atividades de formação continuada para professores como um caminho para melhorar a Educação Básica. Nesse sentido, Fonseca e Ramos (2017) destacam a importância da formação continuada para a atualização dos professores e para o preenchimento de lacunas deixados pela formação universitária. Além disso, outros cursos de formação continuada já se mostraram eficientes, contribuindo para a formação docente e para o processo de ensino-aprendizagem como um todo (BEZERRA, 2012; GREGORIO; MOREIRA, 2020). Apesar disso, identificamos apenas um outro curso de formação continuada de Genética (MARQUES; PERSICH; NETO, 2017), mostrando a importância da criação de mais cursos nessa área.

Os parâmetros quantitativos e qualitativos analisados a partir das respostas dadas pelos professores no formulário de avaliação das alternativas metodológicas também indicam a efetividade do curso. É importante mencionar que apesar das contribuições identificadas no estudo quanto à realização do curso e ao uso das metodologias alternativas, duas limitações precisam ponderadas. A primeira é que a amostra de professores participantes do curso $(n=33)$ não foi tão grande. A segunda está associada a dificuldade em avaliar se os alunos destes professores tiveram as suas dificuldades em Genética reduzidas. Diante desse cenário, de modo a minimizar essas lacunas, todos os 33 professores participantes do curso responderam à um formulário final, realizado um ano e meio após a conclusão do curso.

Os dados coletados por esse formulário nos surpreenderam positivamente, pois mostraram que $82 \%$ dos participantes do curso fizeram uso das metodologias alternativas de ensino de Genética apresentadas no curso. Destes $82 \%, 40 \%(n=13)$ dos docentes afirmaram 
que utilizam frequentemente essas metodologias alternativas, 27\% $(\mathrm{n}=9)$ utilizam algumas vezes, $9 \%(n=3)$ poucas vezes e $6 \%(n=2)$ usaram uma única vez. Apenas $18 \%(n=6)$ dos professores relataram não fazer uso das metodologias alternativas após a conclusão do curso, sendo que metade deles não lecionou Genética nesse período. Portanto, diante dos três instrumentos avaliativos utilizados é possível relatar que o curso "Desenrolando a Genética" contribuiu para minimizar as dificuldades dos professores nesta temática, por meio da revisão teórica dos principais conteúdos ministrados no Ensino Médio e pela apresentação de diferentes propostas de metodologias alternativas de ensino.

A utilização das metodologias alternativas e ativas no ensino de Genética foi positiva e pode ser explicada por duas razões. A primeira é que a utilização destes recursos pode favorecer o aprendizado dos estudantes, pois valorizam as inteligências múltiplas e os diferentes tipos de aprender. O segundo é que pode facilitar a assimilação de conceitos complexos de Genética, pois as metodologias alternativas e ativas dão protagonismo ao estudante. Dessa forma, ao invés de decorar conteúdos, o aluno passa a atuar ativamente na construção do seu aprendizado (SOUZA, 2014; BISSOLI; SANTOS; CONDE, 2018).

Por fim, ao contribuir para a formação continuada dos docentes em Genética, pode-se dizer que o curso "Desenrolando a Genética" atingiu seu objetivo de minimizar as dificuldades no processo de ensino-aprendizagem em Genética ao capacitar os professores de Biologia do Ensino Médio para ensinar Genética. Conforme reportado pelos docentes, o curso contribuiu para uma melhor compreensão dos conteúdos teóricos acerca dessa temática e também permitiu que os docentes conhecessem metodologias alternativas de ensino de Genética. Apesar disso, é importante que investigações adicionais sejam realizadas diretamente com os alunos para verificar se a realização de cursos de formação continuada pelos docentes e o uso de metodologias alternativas de ensino minimizam as suas dificuldades de aprendizado de Genética. Além disso, também é necessário aumentar a realização de cursos de formação continuada em Genética para atingir um maior número de professores.

\section{Considerações Finais}

A aplicação dos questionários de diagnóstico permitiu que identificássemos que as dificuldades de aprendizado dos estudantes em Genética estavam associadas com à complexidade deste conteúdo, sendo maximizadas pelo uso das metodologias tradicionais de ensino (aula expositiva, quadro, giz e livro didático). Além disso, verificamos que o predomínio das aulas tradicionais e a consequente baixa utilização de metodologias alternativas de ensino estavam relacionadas com o fato de muitos professores possuírem defasagens teóricas e práticas nesta temática. Dessa forma, os docentes se sentiam menos desconfortáveis em ensinar esses conteúdos, optando pelo uso da metodologia tradicional de ensino.

É notório que a forma de aprender dos estudantes no século XXI evoluiu e que os docentes precisam buscar novas estratégias de ensino. Nesse sentido, a utilização de recursos didáticos variados, que favorecem a visualização de processos microscópicos, associados às metodologias ativas que asseguram o protagonismo dos estudantes, tem se mostrado uma estratégia exitosa. Mais uma vez, é importante ponderar que os professores devem ser preparados para essa mudança, o que pode ser feito com cursos de formação continuada. Assim, espera-se que eles utilizem esse aprendizado em suas escolas, possibilitando aulas de Genética mais dinâmicas e interessantes para os seus alunos. Nesse contexto, elaboramos o curso "Desenrolando a Genética" contemplando ferramentas que auxiliassem a minimizar as dificuldades teóricas e práticas dos professores. Por fim, a partir dos três instrumentos avaliativos utilizados neste estudo, é possível relatar que o curso "Desenrolando a Genética" 
foi uma ferramenta efetiva para minimizar as dificuldades dos docentes nessa temática, contribuindo com o processo de ensino-aprendizagem de Genética.

\section{Financiamento e agradecimentos}

Nós agradecemos a Coordenação de Aperfeiçoamento de Pessoal de Nível Superior (CAPES/PROAP - Código Financeiro 001) e ao Conselho Nacional de Desenvolvimento Científico e Tecnológico (CNPq) pelo suporte financeiro e bolsas fornecidas.

\section{Referências}

BAHAR, M.; JOHNSTONE, A. H.; HANSELL, M. H. Revisiting Learning Difficulties in Biology. Journal of Biological Education, v. 33, n.2, p. 84-86, 2000.

BELMIRO, M. S.; BARROS, M. D. M. Teaching genetics in high school: a statistical analysis of previous conceptions from pre-university students. Praxis, v. 9, n. 17, p. 95-102, 2017.

BEZERRA, C. L. T. A formação docente como promotora do sucesso discente. \#Tear: Revista de Educação, Ciência e Tecnologia, v. 1, n. 2, p. 1-17, 2012.

BISSOLI, A. C. F.; SANTOS, G. A.; CONDE, S. J. Learning Material Design for Teaching Genetics while implementing Flipped Classroom. Revista Ibero-Americana de Estudos em Educação, v. 13, p. 474-484, 2018.

BREAKLEY, K. M.; LEVIN, D.; MILLER, I.; HENTGES, K. E. The Use of Scenario-BasedLearning Interactive Software to Create Custom Virtual Laboratory Scenarios for Teaching Genetics. Genetics, v. 179, p. 1151-1155, 2008.

CEBESOY, U. B.; OZTEKIN, C. Genetics Literacy: Insights from Science Teachers' Knowledge, Attitude, and Teaching Perceptions. International Journal of Science and Mathematics Education, p. 1-23, 2017.

CHEN, J.; MORAN, S.; GARDNER, H. Multiple Intelligences Around the World. San Francisco: John Wiley \& Sons. Inc, 2009.

DOUGHERTY, M. J.; PLEASANTS, C.; SOLOW, L.; WONG, A.; ZHANG, H.

Comprehensive Analysis of high school Genetics Standards: Are States Keeping Pace with Modern Genetics? CBE - Life Sciences Education, v. 10, p. 318-327, 2011.

DURBANO, J. P. M.; PADILHA, I. Q. M.; REGO, T. G.; RODRIGUES, P. A. L.; ARAÚJO, D. A. M. Percepção do conhecimento dos alunos de ensino médio do município de João Pessoa sobre temas emergentes em biotecnologia. SBG, v. 54, p. 4-11, 2008.

FONSECA, C.V.; RAMOS, F.A. Formação inicial e condições de trabalho de professores de Ciência da Natureza: Estudo de elementos relacionados à formação continuada. \#Tear:

Revista de Educação, Ciência e Tecnologia, v.6, n.1, p.1-16, 2017. 
FONTENELE, M. S.; CAMPOS, F. L. Proposal of a didactic model as a facilitator of the teaching of the DNA structure in a public school in the northern middle region of Piaui, Brazil. spacious, v. 38, n. 45, p. 21 - 32, 2017.

GREGORIO, A.; MOREIRA, A. L. O. R. Temas controversos socioambientais na formação continuada de professores: Analisando a construção e a aplicação de uma sequência didática. \#Tear: Revista de Educação, Ciência e Tecnologia, v. 9, n.1, p. 1-14, 2020.

HAAMBOKOMA, C. Nature and causes of learning difficulties in Genetics at high school level in Zambia. Journal of International Development and Cooperation, v. 13, p. 1-9, 2007

KNIPPELS, M. C. P. J.; WAARLO, A. J.; BOERSMA, K. T. Design criteria for learning and teaching genetics, Journal of Biological Education, v. 39, n. 2, p. 108-112, 2005.

MARQUES, K. C. D.; PERSICH, G. D. O.; NETO, L. C. B. T. Formação continuada para professores de biologia: curso a distância sobre ensino de genética. Encontro Nacional de Pesquisa em Educação de Ciências UFSC, v. 11, p. 1-10, 2017.

MARSHALL J.A.; DURAN, P. Are Biologists Getting the Mathematical Training They Need in College? Biochemistry and Molecular Biology Education, v. 46, n. 6, p. 612-618, 2018.

MEC. Ministério da Educação. Secretaria da Educação Média e Tecnológica. Base Nacional Comum Curricular - Ensino Médio. Brasília: MEC, 2018.

MOSÉ, V. A escola e os desafios contemporâneos. Rio de Janeiro: Civilização Brasileira, 2013.

OECD Indicators. PISA 2018 results. OECD Publishing. Disponível em: https://www.oecdilibrary.org/docserver/5f07c754en.pdf?expires=1576555887\&id=id\&accna me $=$ guest \& checksum=CC37DDECADD4E446F0477F3876A67567. Acesso em: 20 fev. 2020 .

OLIVEIRA, C. I. C. A educação científica como elemento de desenvolvimento: uma perspectiva de construção científica. Ensaio, v. 15, n. 2, p. 105-122, 2013.

SATTERTHWAIT, D. Making biology count: integrating mathematics into the teaching of inheritance. Journal of Biological Education, v. 53, n. 1, p.92-97, 2019.

SHAW, K. R. M.; HORNE, K.; ZHANG, H.; BOUGHMAN, J. Essay Contest Reveals Misconceptions of high school Students in Genetics Content. Genetics Education, v. 178, p. 1157-1168, 2008.

SILVA, C.M.B.; SANTOS, E.O. Formação continuada do professor do ensino médio integrado: concepções e importância. Revista Brasileira de Educação Profissional e Tecnológica, v. 1, p. 1-15, 2020.

SOUZA, R. W. L. Modalidades e recursos didáticos para o ensino de biologia. Revista Eletrônica de Biologia, v.7, p. 124-142, 2014. 
STARBEK, P.; ERJAVEC, M.; PEKLAJ, C. Teaching genetics with multimedia results in better acquisition of knowledge and improvement in comprehension. Journal of Computer Assisted Learning, v. 26, p. 214-224, 2010.

TSUI, C. Y.; TREAGUST, D. F. Understanding Genetics: Analysis of Secondary Students' Conceptual Status. Journal of Research in Science Teaching, v. 44, n. 2, p. 205-243, 2007.

YAMAZAKI, S.C.; YAMAZAKI, R.M.O. Sobre o uso de metodologias alternativas para ensino aprendizagem de ciências. Educação e Diversidade na Sociedade contemporânea, v. 4, p. 1-14, 2006.

Recebido em março de 2021.

Aprovado em maio de 2021.

\section{APÊNDICE}

Apêndice A - Questionário de diagnóstico aplicado com os alunos

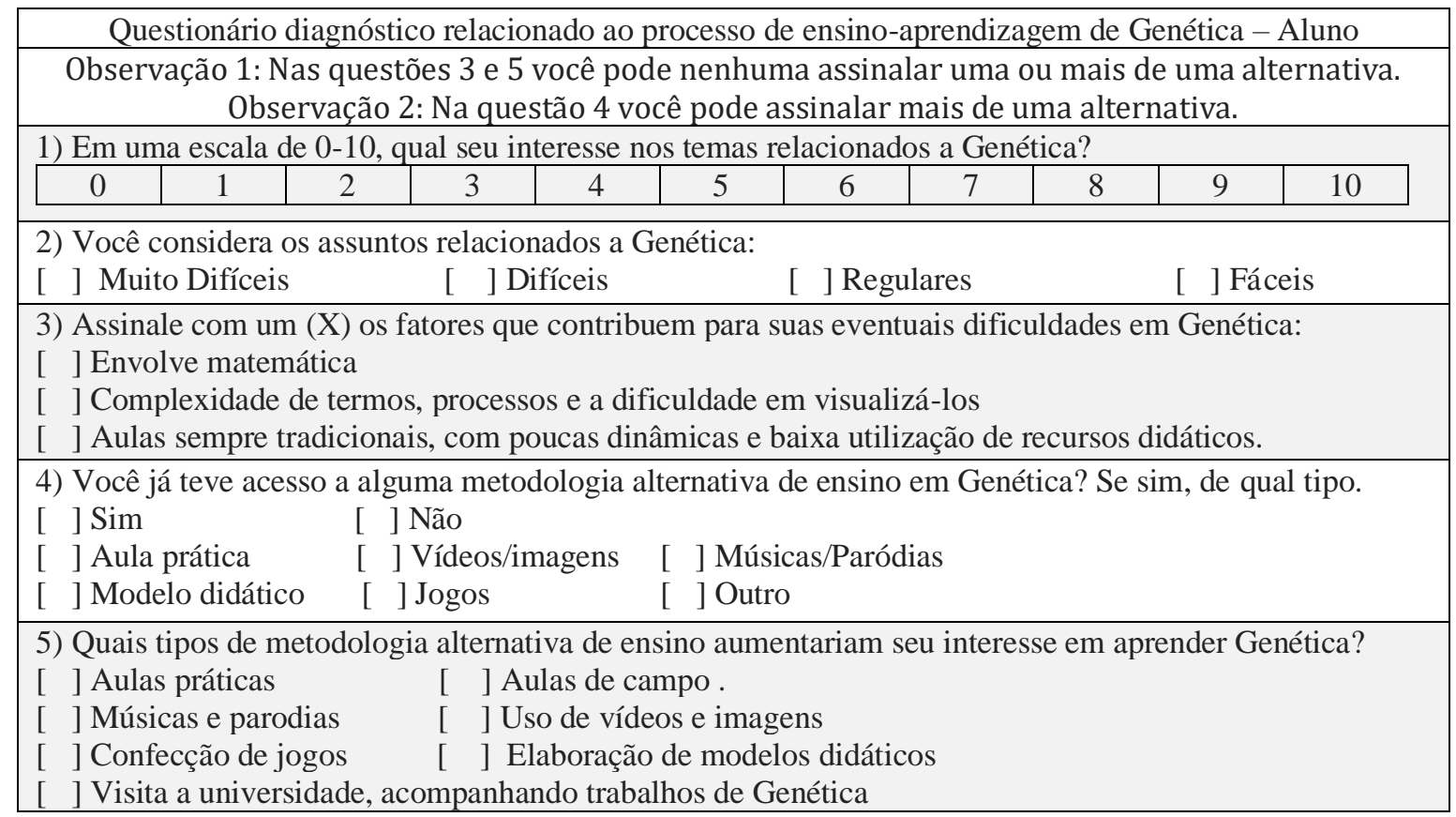

Fonte: Elaborado pelos autores (2018) 
Apêndice B - Questionário de diagnóstico aplicado com os professores

\begin{tabular}{|c|c|c|c|c|c|c|c|c|c|c|}
\hline \multicolumn{11}{|c|}{$\begin{array}{c}\text { Questionário diagnóstico relacionado ao processo de ensino-aprendizagem de Genética - P1 } \\
\text { Observação: Nas questões } 2 \text { e } 3 \text { você pode assinalar mais de uma alternativa. }\end{array}$} \\
\hline \multicolumn{11}{|c|}{ 1) Em uma escala de 0-10 classifique seu interesse por Genética: } \\
\hline 0 & 1 & 2 & 3 & 4 & 5 & 6 & 7 & 8 & 9 & 10 \\
\hline \multicolumn{11}{|c|}{$\begin{array}{l}\text { 2) Que aspectos, indicados abaixo, colaboram para suas dificuldades na Genética: } \\
\text { [ ] Não tenho dificuldades no assunto } \\
\text { [ ] Defasagem teórica - dificuldades em relação ao domínio do conteúdo. } \\
\text { [ ] Defasagem prática - dificuldades em elaborar e ministrar aulas mais dinâmicas }\end{array}$} \\
\hline \multicolumn{11}{|c|}{$\begin{array}{l}\text { 3) Quais fatores abaixo, você considera como obstáculo(s) para ensinar Genética aos seus alunos: } \\
\text { [ ] O envolvimento da matemática } \\
\text { [ ] A complexidade dos termos, processos e a dificuldade em visualizá-los. } \\
\text { [ ] Pouco tempo parar preparar aulas variadas com metodologias alternativas de ensino. } \\
\text { [ ] Minha formação universitária em Genética foi precária. }\end{array}$} \\
\hline \multicolumn{11}{|c|}{$\begin{array}{l}\text { 4) Você já utilizou alguma metodologia alternativa de ensino em suas aulas de Genética? } \\
\text { [ ] Sim [ ] Não }\end{array}$} \\
\hline \multicolumn{11}{|c|}{$\begin{array}{l}\text { 5) Você tem interesse em participar de um curso de extensão de Genética que visa aperfeiçoar os conceitos } \\
\text { e fornecer diferentes formas de ensinar estes conteúdos aos alunos? } \\
\text { [ ] Sim }\end{array}$} \\
\hline
\end{tabular}

Fonte: Elaborado pelos autores (2018)

Apêndice C - Formulário Avaliativo das Metodologias Alternativas

\begin{tabular}{|c|c|c|c|c|c|c|c|c|c|c|c|}
\hline \multicolumn{12}{|c|}{ Formulário para avaliação das dez metodologias alternativas apresentadas durante o curso } \\
\hline \multicolumn{12}{|c|}{$\begin{array}{l}\text { Atenção: Professor, você deverá atribuir uma nota entre } 0 \text { (muito ruim) e } 10 \text { (excelente) para cada uma das } \\
\text { atividades apresentadas e realizadas durante o curso. Além disso, pedimos que acrescente elogios, críticas e } \\
\text { sugestões para cada uma das metodologias alternativas apresentadas. }\end{array}$} \\
\hline 1 - Dicionário de Genética & 0 & 1 & 2 & 3 & 4 & 5 & 6 & 7 & 8 & 9 & 10 \\
\hline 2 - Modelo didático DNA com miçangas & 0 & 1 & 2 & 3 & 4 & 5 & 6 & 7 & 8 & 9 & 10 \\
\hline 3- Jogo sobre a Síntese Proteica & 0 & 1 & 2 & 3 & 4 & 5 & 6 & 7 & 8 & 9 & 10 \\
\hline 4 - Modelo didático do Ciclo celular - Massinha & 0 & 1 & 2 & 3 & 4 & 5 & 6 & 7 & 8 & 9 & 10 \\
\hline 5-Representando genótipos e fenótipos & 0 & 1 & 2 & 3 & 4 & 5 & 6 & 7 & 8 & 9 & 10 \\
\hline 6-Memogene & 0 & 1 & 2 & 3 & 4 & 5 & 6 & 7 & 8 & 9 & 10 \\
\hline 7 - Bingo dos cromossomos sexuais & 0 & 1 & 2 & 3 & 4 & 5 & 6 & 7 & 8 & 9 & 10 \\
\hline 8 - Montando cariótipos & 0 & 1 & 2 & 3 & 4 & 5 & 6 & 7 & 8 & 9 & 10 \\
\hline 9 - Interagindo com a Interação Gênica & 0 & 1 & 2 & 3 & 4 & 5 & 6 & 7 & 8 & 9 & 10 \\
\hline 10 - Bingo Evolutivo & 0 & 1 & 2 & 3 & 4 & 5 & 6 & 7 & 8 & 9 & 10 \\
\hline \multicolumn{12}{|c|}{$\begin{array}{l}\text { ELOGIOS, CRÍTICAS E SUGESTÕES - Utilizando esse espaço e o verso da folha para escrever seus } \\
\text { comentários para cada uma das dez práticas realizadas }\end{array}$} \\
\hline
\end{tabular}

Fonte: Elaborado pelos autores (2018) 
Apêndice D - Questionário aplicado um ano e meio após o final do curso Formulário para mensurar o uso das metodologias alternativas em sala de aula

Atenção: Professor, seja sincero ao avaliar a sua utilização das metodologias alternativas de ensino de Genética apresentadas no curso, durante esse período de um ano e meio após a conclusão do curso.

1 - Com que frequência você utilizou as metodologias alternativas apresentadas no curso após a sua conclusão

( ) Utilizei frequentemente

( ) Utilizei algumas vezes

( ) Utilizei poucas vezes

( ) Utilizei uma vez

( ) Não utilizei

2 - Caso queira fazer algum comentário sobre a utilização das metodologias, utilize esse espaço:

Fonte: Elaborado pelos autores (2018) 